\title{
Salt and
}

\section{Brazilian ancestry}

Rodrigo Díaz 0 Imos, Isabela Martins Benseñor

Salt and humanity are very old companions. The agricultural revolution started ten thousand years ago, and salt was responsible for where human populations settled because of its food conservation properties.

PopulationsliketheYanomani that do not use salt for preparing food do not like it when salt is added in, as was the case with the Yanomani in the 1980's. H owever, after three months of eating salted foods, people become addicted to salt and it is impossible to take the salt out from their diet. So, everyonein our modern civilization is a salt addict. This has also happened with the Yanomani, who now add much more salt in their food preparation.

Evidencefor theassociation between salt and hypertension has been found in ancient Chinese manuscripts and throughout history. D uring the twentieth century, a lot of information was accumulated regarding salt and hypertension but one of themost important studies about this association was produced in the 1980's: the Intersalt Study. ${ }^{1}$

Intersalt was a multicentric study involving 52 centers in 32 different countries. The study included 200 people in each center, making atotal of 10,000 men and women. Four remote populations were included in this study (Yanomani, Xingu, and from Kenya and Papua-N ew Guinea). In these four centers salt ingestion measured by sodium excretion in 24hour urinesampleswas lower when compared to other centers. People from the four remote populations also had a lower body massindex (BM I), more daily physical activity and a lower ingestion of alcohol. Intersalt concluded that a salt ingestion of $100 \mathrm{mmol}$ less every day over a long time represented 2 to $3 \mathrm{mmH}$ g less in blood pressure
What is the significance of these numbers? For each individual, very little but for populations this is very important. When associated with other factors such as lower BMI, alcohol intake and increased physical activity, the decrease in systolic blood pressure can reach $9 \mathrm{mmH} \mathrm{g}$, which represents a re duction of $16 \%$ in the prevalence of coronary heart disease, $23 \%$ in stroke and $13 \%$ in all-cause mortality.

Intersalt concluded that although there are a lot of factors influencing blood pressure levels, salt is still a very important one. Another conclusion was in relation to the Epstein-Eckoff curve, which generally shows an increased prevalence of high blood pressure levels with increasing age. Until the Intersalt data, this fact was considered normal for all populations. The four remote populations in Intersalt proved this is not correct. Blood pressurelevels do not increase with age for these populations.

$$
\begin{gathered}
\text { Why thisisso } \\
\text { important for. Brazil? }
\end{gathered}
$$

Cardiovascular mortality istheleading cause of death in Brazil. ${ }^{2}$ In some places like the Southeast, most of the cardiovascular deaths are from coronary heart disease. H owever, in the $\mathrm{N}$ ortheast, most of the mortality is due to stroke. The most important risk factor for stroke is high blood pressure. The Brazilian heritage originates from Portugal and Portuguesetradition includes a lot of salt in foods like codfish, sausages and other very tasty dishes that form part of our lives. Bread in thePortuguese tradition also has a lot of salt, and Brazilian bakeries follow the Portugueseinfluence. So theEpstein-Eckoff

“...um mal secreto, não o do soneto, mas o de qualquer doença, ésempreum fator de tranquilidade. Q uem não sabenão teme. Como diagnóstico da pressão alta não ésegui do de tratamento ou ajuda, para muita gente simplesé só alarme. A viúva gorda e patusca, que tem um cotidiano insosso, é convidada a cortar o sal do seu fejjão com arroz... curve for the Brazilian population in se lected data is very similar to the Portuguese curve: there is a sharp increase in blood pressure levels according to age.

So, possibly, hypertension is the most important risk factor for cardiovascular disease in Brazil, with morerelevance than cholesterol levels.

Brazilian peoplearesalt-addicted like almost every other people in the world, but with a high slope on the EpsteinEckoff curve because of our Portuguese heritage. What isthe point? Salt isstill an important causal factor in the genesis of hypertension, although a lot of other factorscan also interfere Industrialized foods also have a lot of salt used for conservation, as does our Portuguese heritage. Hypertension control in Brazil should include a change in our habits regarding saltintake. Thisisthemost difficult thing: it is very hard to change habits and traditions that come from our mothers.

In a not so good translation from O tto Lara Rezende,

“....an unrevealed ailment, not like those in the sonnets but as found in any disease, is al ways a matter for tranquillity. What you don't know, you don't have. As adiagnosis of high pressureisnot followed by treatment or assistance, it is for many ordinary peoplejust an alarm. Thefat and frolicsome widow who has a dull day-byday life is invited to cut out the salt from her rice and beans..."

Isabela Martins Benseñor, MD, PhD. Assistant Professor in the Division of Clinical Medicine, Hospital das Clínicas, Universidade de São Paulo, São Paulo, Brazil.

Rodrigo Díaz Olmos. Resident-in-C hief, Hospita das Clínicas, Hospital das Clínicas, Universidade de São Paulo, São Paulo, Brazil.

\section{REFERENCES}

1. Stamler J, RoseG, Rlliott P, D yer A, M armot M, Kesteloot $H$, Stamler R. Findings of the International Cooperative Intersalt Study. Hypertension 1991;17:SI-9/SI-15.

2. Lotufo PA. Premature mortality from heart diseases in Brazil. A comparison with other countries. Arq Bras Cardiol 1998;70(5):321-5. 